\title{
Genotypic Analysis of Staphylococcus aureus Coagulase Gene using PCR-RFLP analysis
}

\author{
Reza Hakimi Alni (MSc) \\ Department of Pathobiology, Faculty \\ of Veterinary Science, Bu-Ali Sina \\ University, Hamedan, Iran \\ Abdolmajid Mohammadzadeh \\ (PhD) \\ Department of Pathobiology, Faculty \\ of Veterinary Science, Bu-Ali Sina \\ University, Hamedan, Iran \\ Pezhman Mahmoodi (PhD) \\ Department of Pathobiology, Faculty \\ of Veterinary Science, Bu-Ali Sina \\ University, Hamedan, Iran \\ Mohammad Yousef Alikhani (PhD) \\ Department of Microbiology, Faculty \\ of Medicine, Hamadan University of \\ Medical Sciences, Hamadan, Iran \\ Corresponding Author: Abdolmajid \\ Mohammadzadeh \\ Email: mohammadzadeh@basu.ac.ir \\ Tel: +9881344227350 \\ Address: Department of Pathobiology, \\ Faculty of Veterinary Science, Bu-Ali \\ Sina University, Hamedan, Iran
}

Received : 30 May 2017

Revised: 02 Sep 2017

Accepted: 11 Sep 2017
ABSTRACT

Background and Objectives: Determining the genetic relationship between $S$. aureus isolates is important for epidemiological surveillance and control of infections caused by this bacterium. The present study was conducted to determine polymorphisms of coagulase gene (coa) among $S$. aureus isolates from pastry and cheese samples using restriction fragment length polymorphism (RFLP) analysis.

Methods: 0verall, 65 S. aureus isolated from pastry $(\mathrm{n}=45)$ and cheese $(\mathrm{n}=20)$ samples were examined for the coa gene by polymerase chain reaction (PCR). PCR products were digested with Alul enzyme and the products were assessed using gel electrophoresis.

Results: Except for two isolates, all isolates were positive in coa-PCR and produced four different PCR products, with molecular sizes ranging from 570 to 970 bp. Overall; five distinct RFLP patterns were detected (I-V). Although pattern types I and III were present in isolates from both samples, types I and IV were mainly present in isolates from cheese and pastry samples, respectively.

Conclusion: PCR-RFLP analysis of the coa gene indicates that $S$. aureus isolates from pastry and cheese samples may be originated from different sources. However, as one pattern type was predominant in each group, it can be concluded that majority of the isolates may have the same origin.

Keywords: Staphylococcus aureus, PCR-RFLP, Coagulase, Pastry, Cheese. 


\section{INTRODUCTION}

Staphylococcus aureus is the second most important cause of foodborne diseases (1), which can be transmitted through milk and dairy products (2). Bacterial contamination in these products, directly from animals or from humans during production, may lead to food poisoning (3). For effective prevention and control of $S$. aureus infections, possible source(s) of infections should be identified by typing of isolates using different methods (4). In the past few years, various molecular techniques including pulsed field gel electrophoresis and multilocus sequence typing have been used for discrimination of $S$. aureus isolates $(5,6)$. However, these methods are time consuming, not widely available and expensive (7). On the other hand, polymerase chain reaction (PCR)-based typing methods such as PCR-restriction fragment length polymorphism (PCR-RFLP) and random amplified polymorphic DNA-PCR are cheaper and have high discriminatory power and reproducibility $(8,9)$.

Various polymorphic genes such as coagulase gene (coa) can be targeted for typing of $S$. aureus isolates. Pathogenic staphylococci produce coagulase, an extracellular virulence factor that can cause plasma coagulation. In fact, it acts as a cofactor and induces a conformational change in prothrombin, which converts fibrinogen to fibrin (10). Since this enzyme has polymorphic repeat regions in its $3^{\prime}$ end sequence, it is thought that RFLP analysis of the coa gene could be useful for typing of $S$. aureus strains (11). Variable region of the coa gene is composed of $81 \mathrm{bp}$ tandem short sequence repeats (SSRs) that encode tandem repeats of 27 amino acids in the C-terminal region. Difference in the number of SSRs and its mutations may cause distinct PCR amplification of this region and lead to generation of DNA fragments of different sizes, which could be discriminated further by digestion with restriction enzymes such as AluI (12). The present study was conducted to describe genotypic variations among $S$. aureus strains isolated from pastry and cheese samples.

\section{MATERIAL AND METHODS}

The study included $65 \mathrm{~S}$. aureus strains isolated from pastry $(n=45)$ and cheese $(n=20)$ samples between November 2014 and April 2015. Identity of all isolates was confirmed by biochemical tests and species-specific PCR (data are not shown).

DNA was extracted from $10 \mathrm{ml}$ overnight cultures of the isolates in tryptic soy broth (Merck, Germany) using phenol-chloroform method as described previously (13).

The DNA samples were amplified by PCR assay using coa-specific primers (Table 1) (14). The PCR reaction solution $(50 \mu \mathrm{l})$ contained $5 \mu \mathrm{l}$ of template DNA, $5 \mu \mathrm{l}$ of $10 \times$ PCR buffer (500 mM, KCL and Tris HCL, pH 8.4), $1 \mu \mathrm{l}(25 \mathrm{mM})$ of $\mathrm{MgCl}_{2}, 1 \mu \mathrm{l}(200 \mathrm{mM})$ of dNTPs, $1 \mu \mathrm{l}(50 \mathrm{pmol})$ of each primer (SinaClon, Iran), $35 \mu 1$ of distilled water and 2 U Taq DNA polymerase (SinaClon, Iran). The amplification process was performed under the following conditions: initial denaturation at 94 ${ }^{\circ} \mathrm{C}$ for 5 min followed by denaturation at $94{ }^{\circ} \mathrm{C}$ for $60 \mathrm{sec}$, annealing at $58{ }^{\circ} \mathrm{C}$ for $90 \mathrm{sec}$ and extension at $72{ }^{\circ} \mathrm{C}$ for $90 \mathrm{sec}(32$ cycles) and a final extension at $72{ }^{\circ} \mathrm{C}$ for $10 \mathrm{~min}$ (15). The PCR products were electrophoresed on $1 \%$ agarose gel containing ethidium bromide $(0.5$ $\mu \mathrm{g} / \mathrm{ml})$.

\section{RFLP}

The PCR products were purified using commercial gel purification kits (Vivantis, Malaysia), and digested with $A l u \mathrm{I}$ enzyme (Fermentas, USA). Then, $10.5 \mu \mathrm{l}$ of distilled water, $2.5 \mu \mathrm{l}$ of $10 \times$ restriction buffers and 7 $\mu \mathrm{l}$ of the purified PCR products were mixed with $2 \mathrm{U}$ of $A l u I$. The mixture was incubated at $37{ }^{\circ} \mathrm{C}$ for 1 hour (14). The PCR products digested were electrophoresed on $2 \%$ agarose gel at $90 \mathrm{~V}$ for approximately $70 \mathrm{~min}$. Finally, the patterns obtained from the RFLP assay were analyzed using GelCompar II software (version 6.5). The similarity index was calculated using the Dice coefficient with a band position tolerance of $1 \%$. In addition, the unweighted-pair group method was used to construct a dendrogram, and clusters were selected using a cutoff of $40 \%$.

Table 1- Primers used for amplification of the coa gene

\begin{tabular}{ccc}
\hline Primer & Sequence 5' - 3' & Product size (bp) \\
\hline COAG2-F & ATAGAGATGCTGGTACAGG & $570-970$ \\
COAG3-R & GCTTCCGATTGTTCGATGC & \\
\hline
\end{tabular}




\section{RESULTS}

In PCR amplification of the coa gene, all isolates from cheese samples generated three DNA fragments ranged $\sim 860$ to $\sim 970 \mathrm{bp}$ (Figure 1). The most frequent $(60 \%)$ PCR product among isolates from cheese was a 970-bp DNA band. On the other hand, 95.6\% (43) of the $S$. aureus isolates from pastry samples contained the coa gene, and yielded 570, 860 and 970 bp DNA bands (Figure 1). However, two isolates (4.5\%) did not show any band. Moreover, $74.4 \%$ of the isolates showed the $860 \mathrm{bp}$ band. Later, RFLP was used to demonstrate polymorphisms of the coa gene among the $S$. aureus isolates. As shown in table 2, digestion of the PCR products with
AluI yielded different restriction patterns for isolates from pastry (4) and cheese (3) samples. The most frequent pattern in isolates from pastry was type IV, while type I was the most common pattern observed in isolates from cheese. Moreover, types I and III restriction patterns were common among the isolates from cheese and pastry (Figure 2). Based on the dendrogram generated, S. aureus isolates were divided into two major clusters (A and B) and four subclusters (Figure 2). All strains in subcluster A-1 were isolated from pastry samples. However, strains in cluster B and subcluster A-2 were isolated from pastry and cheese samples.

Figure 1- Amplification of the coa gene in $S$. aureus isolates from pastry (A) and cheese (B) samples. L: 100 bp DNA ladder, column 1: positive control ( $S$. aureus ATCC 25923), column 2: negative control (no template DNA), columns 3-5: $S$. aureus isolates
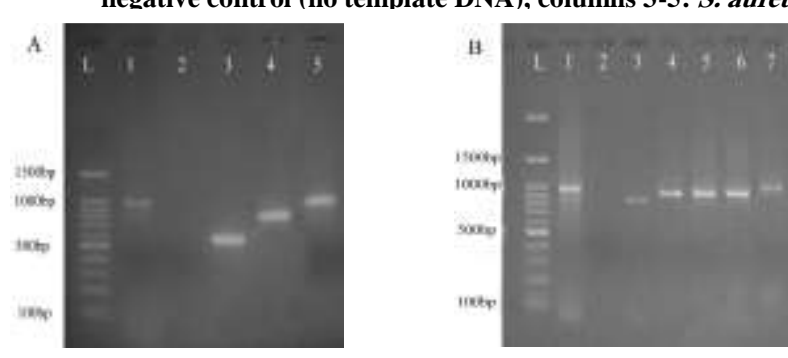

Table 2- Types of $S$. aureus isolates based on the RFLP patterns for the coa gene

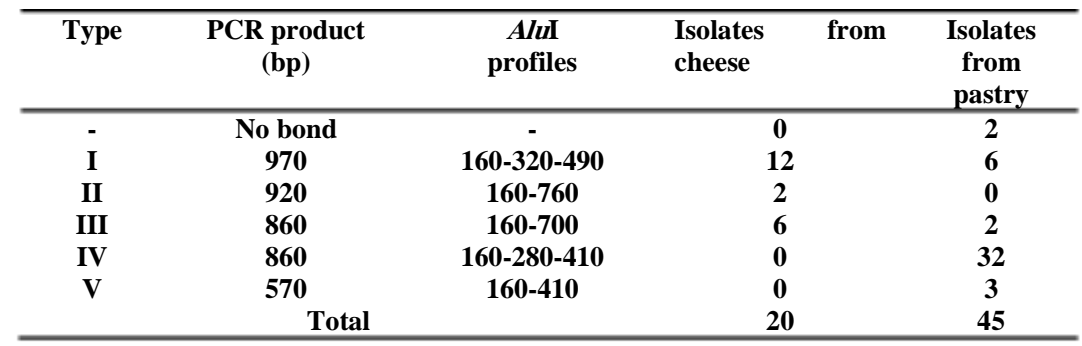

Figure 2- RFLP patterns obtained from digestion of PCR products. Column 1: type IV, column 2: tvpe I. column 3: tvpe V. column 4: tvpe III. column 5: tvpe II

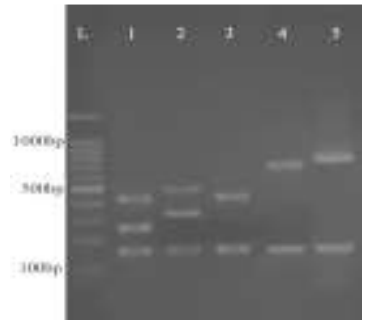

Figure 3- Dendrogram of genetic relationship among various RFLP types in $S$. aureus isolates
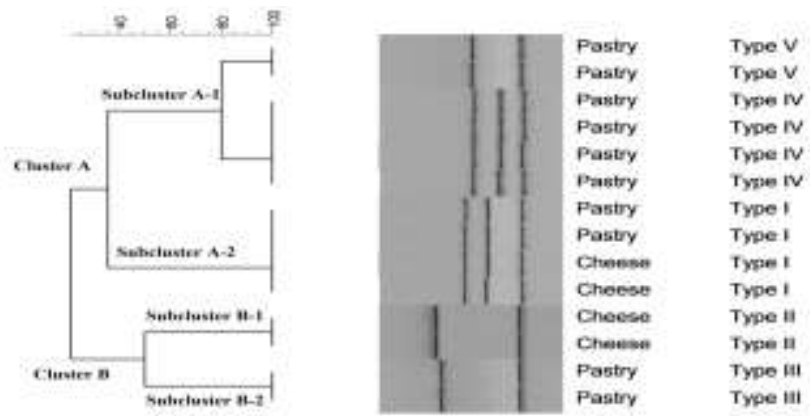


\section{DISCUSSION}

Coagulase is one of the virulence factors of $S$. aureus, which may contribute to its pathogenicity (16). The enzyme is encoded by the coa gene, which is highly polymorphic at its $3^{\prime}$ end. PCR amplification of this gene may yield amplicons of different sizes, which could be useful for differentiation of $S$. aureus isolates and determination of the possible source of infection.

In the present study, PCR amplification of the coa gene revealed significant differences between $S$. aureus isolates from pastry and cheese samples. Generally, all isolates from cheese were coa-positive and only two isolates (4.44\%) from pastry were coa-negative. In accordance with these results, some studies have previously shown that $S$. aureus isolates may be negative for the coa gene. Momtaz et al. reported that only 42 of 86 S. aureus isolates in milk samples from bovine mastitis cases contained the coa gene in PCR-RFLP analysis (17). In study of Karahan and Cetinkaya, the coa gene was detected in $80.5 \%$ of $S$. aureus strains isolated from subclinical cases of mastitis (14). However, using the same coa-specific primers, the percentage of coa-positive isolates was much higher $(97 \%)$ in our study. Nevertheless, findings of some studies were consistent with our findings (18, 19).

We found that 32 of 45 isolates from pastry showed an 860 bp DNA fragment in PCR. However, the majority of isolates from cheese showed a 970 bp DNA fragment related to the coa gene. Generally, the size of the coa gene in isolates from cheese was larger than that in isolates from pastry. In line with our results regarding isolates from pastry, some studies have reported that the coa gene PCR products from $S$. aureus isolates of human origin could be $650-900$ bp long (20).

Tiwari et al. analyzed the coa gene in clinical and nasal $S$. aureus isolates using the same primers used in our study. They reported that the size of the gene might be $300-800 \mathrm{bp}$, and the $600 \mathrm{bp}$ as the most common DNA fragment (19). In a study by Reinosoa et al. in Argentina, PCR amplification of the coa gene in $S$. aureus isolates from human, bovine and food samples yielded seven different coa types with amplicon sizes between 400 and $1000 \mathrm{bp}$ (21). In study of Scherrer et al., 285 (97.3\%) of $293 \mathrm{~S}$. aureus isolated from raw milk samples showed a single DNA band (500-820 bp) in PCR of the coa gene. In RFLP analysis of PCR products with $A l u \mathrm{I}$, they reported six different restriction patterns (A-F) with pattern B (80-180-210) as the most common type. In addition, they reported different coa-RFLP patterns among $S$. aureus isolates from goat, sheep and bovine milk samples (22). Momtaz et al. reported the presence of certain coa genotypes of $S$. aureus in cases of mastitic in dairy herds in Isfahan, Iran (17). Talebi-Satlou et al. reported tissue-specific tendency in RFLP analysis of the coa gene variants among $26 \mathrm{~S}$. aureus isolates from different human tissues (23). Omar et al. reported that coaRFLP analysis of $S$. aureus isolates was more useful for local epidemiologic purposes (24).

In the percent study, all PCR products were digested with $A l u \mathrm{I}$ and five distinct (I-V) RFLP patterns were detected. Little similarity was found between isolates from pastry and cheese samples. Pattern types IV and V were only detected in isolates from pastry, while pattern type II was only detected in isolates from cheese. However, at 35\% similarity, the dendrogram showed that $S$. aureus isolates from pastry samples were only slightly related to the isolates from cheese samples. These results indicate that these isolates may be of different origin (humans or animals). In this regard, we have previously found that most human- and bovine-associated $S$. aureus isolates produce $860 \mathrm{bp}$ and $970 \mathrm{bp}$ DNA fragments in coa-PCR (data have not yet been published), respectively. Pastry isolates may originate from humans, whereas cheese isolates could belong to bovine milk. However, some isolates from both samples shared the same RFLP patterns (types I and III). This indicates that such strains may circulate among different sources or hosts. Consistent with our findings, some studies suggested transmission of $S$. aureus between animals, humans and food samples $(25,26)$.

\section{CONCLUSION}

The present study demonstrated that $S$. aureus isolates from pastry and cheese samples are genetically diverse, and can be typed by coa-PCR-RFLP analysis. According to the results of RFLP, there is only a slight similarity between pattern of isolates from pastry and cheese samples, suggesting that these isolates may be of different origin. However, one 
pattern type was predominant among the isolates from both samples, which could indicate their common origin of infection.

\section{ACKNOWLEDGEMENTS}

This article has been derived from a $\mathrm{PhD}$

\section{REFERENCES}

1. Normanno G, Firinu A, Virgilio S, Mula G, Dambrosio A, Poggiu A, et al. Coagulase-positive Staphylococci and Staphylococcus aureus in food products marketed in Italy. Int J Food Microbiol. 2005; 98(1): 73-9.

2. Bendahou A, Lebbadi M, Ennanei L, Essadqui FZ, Abid M. Characterization of Staphylococcus species isolated from raw milk and milk products (lben and jben) in North Morocco. J Infect Dev Ctries. 2008; 2(03): 21825.

3. Normanno G, La Salandra G, Dambrosio A, Quaglia $\mathrm{N}$, Corrente M, Parisi A, et al. Occurrence, characterization and antimicrobial resistance of enterotoxigenic Staphylococcus aureus isolated from meat and dairy products. Int J Food Microbiol. 2007; 115(3): 290-6. DOI:10.1016/j.ijfoodmicro.2006.10.049

4. Mehndiratta P, Bhalla P. Typing of Methicillin resistant Staphylococcus aureus: a technical review. Indian J Med Microbiol. 2012; 30(1):16-23. doi: 10.4103/0255-0857.93015.

5. Laplana LM, Cepero MPG, Ruiz J, Zolezzi PC, Calvo MCR, Erazo MC, et al. Molecular typing of Staphylococcus aureus clinical isolates by pulsed-field gel electrophoresis, staphylococcal cassette chromosome mec type determination and dissemination of antibiotic resistance genes. Int J Antimicrob Agents. 2007; 30(6): 505-13. DOI:10.1016/j.ijantimicag.2007.06.020.

6. Larsen J, Enright MC, Godoy D, Spratt BG, Larsen AR, Skov RL. Multilocus sequence typing scheme for Staphylococcus aureus: revision of the gmk locus. J Clin Microbiol. 2012; 50(7): 2538-9. doi: 10.1128/JCM.00290-12.

7. Tenover FC, Arbeit R, Archer G, Biddle J, Byrne S, Goering $\mathrm{R}$, et al. Comparison of traditional and molecular methods of typing isolates of Staphylococcus aureus. J Clin Microbiol. 1994; 32(2): 407-15.

8. Hookey JV, Richardson JF, Cookson BD. Molecular typing of Staphylococcus aureus based on PCR restriction fragment length polymorphism and DNA sequence analysis of the coagulase gene. J Clin Microbiol. 1998; 36(4): 1083-9.

9. Alni RH, Mohammadzadeh A, Mahmoodi P, Alikhani MY. RAPD-PCR analysis of Staphylococcus aureus strains isolated from different sources. Comp Clin Path. 2017; 26(4): 823-830.

10. Friedrich R, Panizzi P, Fuentes-Prior P, Richter K, Verhamme I, Anderson PJ, et al. Staphylocoagulase is a prototype for the mechanism of cofactor-induced zymogen activation. Nature. 2003; 425(6957): 535-9. DOI:10.1038/nature01962. thesis by Mr Hakimi, and was financially supported by the Bu-Ali Sina University of Hamedan.

\section{CONFLICT OF INTEREST}

The authors declare that there is no conflict of interest.

11. Wichelhaus TA, Hunfeld K-P, Böddinghaus B, Kraiczy P, Schafer V, Brade V. Rapid molecular typing of methicillin-resistant Staphylococcus aureus by PCRRFLP. Infect Control Hosp Epidemiol. 2001; 22(05): 294-8.

12. Van Belkum A, Scherer S, Van Alphen L, Verbrugh $\mathrm{H}$. Short-sequence DNA repeats in prokaryotic genomes. Microbiology and Molecular Biology Reviews. 19981; 62(2): 275-93.

13. Wilson K. Preparation of genomic DNA from bacteria. Curr Protoc Mol Biol. 2001; 2(4): 1-2.

14. Goh SH, Byrne S, Zhang J, Chow A. Molecular typing of Staphylococcus aureus on the basis of coagulase gene polymorphisms. J Clin Microbiol. 1992; 30(7): 1642-5.

15. Karahan M, Cetinkaya $\mathrm{B}$. Coagulase gene polymorphisms detected by PCR in Staphylococcus aureus isolated from subclinical bovine mastitis in Turkey. Vet J. 2007; 174(2): 428-31. DOI:10.1016/j.tvj1.2006.05.016.

16. Aarestrup FM, Dangler C, Sordillo L. Prevalence of coagulase gene polymorphism in Staphylococcus aureus isolates causing bovine mastitis. Can J Vet Res. 1995; 59(2): 124-128.

17. Momtaz H, Tajbakhsh E, Rahimi E, Momeni M. Coagulase gene polymorphism of Staphylococcus aureus isolated from clinical and sub-clinical bovine mastitis in Isfahan and Chaharmahal va Bakhtiari provinces of Iran. Comp Clin Path. 2011; 20(5): 519-22.

18. Khan A, Hussain R, Javed MT, Mahmood F. Molecular analysis of virulent genes (coa and spa) of Staphylococcus aureus involved in natural cases of bovine mastitis. Pak J Agric Sci. 2013; 50: 739-43.

19. Tiwari HK, Sapkota D, Gaur A, Mathuria JP, Singh A, Sen MR. Molecular typing of clinical Staphylococcus aureus isolates from northern India using coagulase gene PCR-RFLP. Southeast Asian J Trop Med Public Health. 2008; 39(3): 467-73.

20. Mahmoudi H, Arabestani MR, Mousavi SF, Alikhani MY. Molecular analysis of the coagulase gene in clinical and nasal carrier isolates of methicillin-resistant Staphylococcus aureus by restriction fragment length polymorphism. J Glob Antimicrob Resist. 2017; 8: 41-45. doi: 10.1016/j.jgar.2016.10.007.

21. Reinoso E, El-Sayed A, Lämmler C, Bogni C, Zschöck M. Genotyping of Staphylococcus aureus isolated from humans, bovine subclinical mastitis and food samples in Argentina. Microbiol Res. 2008; 163(3): 314-22. 
22. Scherrer D, Corti S, Muehlherr J, Zweifel C, Stephan R. Phenotypic and genotypic characteristics of Staphylococcus aureus isolates from raw bulk-tank milk samples of goats and sheep. Vet Microbiol. 2004; 101(2): 101-7.

23. Talebi-Satlou R, Ahmadi M, Dastmalchi Saei H. Restriction fragment length polymorphism genotyping of human Staphylococcus aureus isolates from two hospitals in urmia region of iran using the coa gene. $\mathrm{J} \mathrm{J}$ Microbiol. 2012; 2(3): 416-20.[Persian].

24. Omar NY, Ali HA, Harfoush RA, El Khayat EH. Molecular typing of methicillin resistant Staphylococcus aureus clinical isolates on the basis of protein $A$ and coagulase gene polymorphisms. Int J Microbiol. 2014; 15: 1-11. doi: 10.1155/2014/650328.

25. Lee JH. Methicillin (oxacillin)-resistant Staphylococcus aureus strains isolated from major food animals and their potential transmission to humans. Appl Environ Microbiol. 2003; 69(11): 6489-94.

26. Nnachi AU, Emele FE, Ukaegbu CO, Agah MV, Udu-Ibiam OE, Chukwu OS, et al. Prevalence of methicillin-resistant Staphylococcus aureus (MRSA) in raw meat and meat handlers in Onitsha, Nigeria. Europ J Prev Med. 2014; 2: 9-15. doi: 10.3390/ijerph13100949. 